\title{
An Understanding of the Trends in the Free Secondary Education Funding Policy and Transition Rates from Primary to Secondary Education in Kenya
}

\author{
Hilda Njeri Wanja \\ Mount Kenya Universit, School of Education
}

\author{
Doi:10.5901/jesr.2014.v4n1p133
}

\begin{abstract}
Sessional Paper No. 12005 proposed a policy integrating secondary education as part of basic education in Kenya. This poses a great challenge to the country in ensuring access to secondary education for all primary school graduates since many are unable to proceed with post-primary education. Apart from the year 2004 when the rates increased to 50.5\% as statistics indicate, a study conducted by Africa Population and Health Research Centre APHRC (2007) observed that the majority of children in Sub-Saharan Africa do not make it to secondary school. Analysis of Gross Enrollment Rate (GER) shows that twothirds of all countries with secondary GER of $40 \%$ and below are in Africa. Financing secondary education is a great challenge to both governments and households. In Kenya whereas households meet negligible cost to meet primary education and about $20 \%$ for university education costs, they shoulder $60 \%$ of secondary education costs. Thus, cost is a key barrier to transition to secondary school for the poor, who form the majority in Kenya (APHRC, 2007). Since the inception of FSE policy funding there is no known study that has been done on effect on transition rates from primary to secondary schools. The purpose of this paper is to discuss effect of free secondary education funding policy on transition rates from primary to secondary sub-sectors in Kenya. The paper argues that major factors which contribute to decline in transition rates at any level of schooling include financial constraints, poor academic performances, negative attitude towards education and peer influence. The paper further presents that high inflation rates, understaffing, delayed disbursement of funds, insufficient funds, are challenges that affect implementation of Free Secondary Education policy in Kenya. As a result, Free Secondary Education negatively affects the quality of education.
\end{abstract}

Keywords: Education, Funding, Transition rates, Free, Challenges, Planning, Policy

\section{Introduction}

Formal secondary education in Kenya is the $2^{\text {nd }}$ level in the education system which caters for $14-18$ years within the school system (MOEST, 2005). The massive increase in enrollment in primary schools following the introduction of Free Primary Education (FPE) is already putting pressure on the demand for access to secondary education. The immediate challenge of secondary education is how to expand access at relatively low cost while improving the quality of education at the same time. The momentum for rapid and urgent expansion of secondary education would become more crucial as FPE becomes more universal.

Challenges of FPE in Kenya Assessment Report on sustainability, poses a question of "After FPE What Next?", in line to this puzzle all stakeholders are asking the government to lower fees for secondary education to make it more affordable. To sustain FPE the post Primary education must develop very fast. Beside, there is little alternative than to set up a full scholarship funds for secondary education and more so for the orphans and the most vulnerable groups to access secondary education as a basic right (MOEST, 2004).

In consideration of the constraints facing secondary education sub-sector, sessional paper No. 1 (2005) identify low transition rate from primary to secondary as mainly caused by the rising cost of financing secondary education by many households. MOEST suggested an initiative and key priority including implementation of Free Secondary Education (FSE) along the same line as FPE programme in all public secondary schools with effect from January 2008. The government of Kenya (GOK) specific target was to achieve transition rates of $70 \%$ in 2008 and $80 \%$ in 2012 from primary to secondary school level from the then rate of $50 \%$ (2005). The government aimed to have $90 \%-100 \%$ completion rates by 2015. This is in order for the government to provide globally competitive quality and relevant education and training to all learners. Since the year 2008 January, the government of Kenya through MOEST implemented FSE funding policy which has led to an increase in the number of secondary school students in recent years. The implementation of the affordable secondary education (ASE) has been done by providing Kenya shillings 10,265 per year per student in all public secondary schools. A pertinent question one has to ask at this point; what effect 
does the funding of secondary school education sub-sector have on the transition rates from primary sub-sector to secondary sub-sector.

\section{Theoretical Bases of Free Education}

The classical liberal theory of equal opportunity asserts that each person is born with given amount of capacity, which to a large extent is inherited and cannot be substantially changed. Thus educational systems should be designed so as to remove barriers of any nature whether economic, gender or geographic, that prevent bright students from lower economic backgrounds from taking advantage of inborn capacity, which accelerate them to social promotion. Liberal progrevists such as Horace Mann (1712-1778) termed education as 'the Great Equalizer' which would enhance life chances of those born into humble circumstances. Classical liberal theory demands for further going through all educational levels to which access would be determined on the basis of individual merit and not on social background. The criteria of the scholastic promotion should be "ability and will" (Petrat 1969). A system financial aid that is expected to set in motion an intensive social mobility by facilitating an open competition where the able would get access to careers that they deserve.

By making secondary education affordable, the government meant making basic education available to all children regardless of their social classes. It is hoped that the handicaps that are inherited in being poor have been removed. On the level of education policy, the problem is mainly seen as of providing grants for the poor and able pupils, especially at secondary school level in Kenya, (Njeru \& Orodho, 2003).

Classical liberal theory states that social mobility will be promoted by equal opportunity of education. American Declaration of Independence claimed that all people are created equal that is, people are born with the same moral and political rights. It follows from the belief that social institution such as education should be in some sense attempt to treat people equally. There are innumerable examples of people from poor families who have taken advantage of education opportunities and proceeded to obtain better jobs and higher incomes than would otherwise do. If the state did not provide affordable education, these individuals would have been denied the opportunity for advancement. Therefore, by removing economic barriers there will be creation of equal opportunity, where everybody has access to the kind and amount of education that suit his or her inherited capacity. In the past, a great deal of weight has been attached to education as a vehicle of equalization and it has generally been assumed that increased public spending on education, which contributes to this end reduces dropout, repetition and absenteeism of poor children (OECD, 1975).

In developing countries there is a widespread inequality of educational provisions. This leads to inequality of participation which means that the benefits of education are disproportionately enjoyed by the upper income families whose children are far more likely to complete the primary and secondary school cycle or enroll in higher education (Psacharopoulos \& Woodhall, 1985). In Kenya the government has made secondary education affordable through FSE funding policy in a bid to enhance access to basic education. This is after the government declared secondary education as an integral part of basic education.

In conclusion the theory suggests that social mobility can be promoted by equal opportunity of education. Therefore, this theory was relevant for the study because provision of FSE policy in Kenya promoted equal opportunity and enhanced transition from primary to secondary sub-sector of education. The study sought to investigate the effects of FSE funding on transition rates from primary to secondary sub-sector, which intern would promote social mobility regardless of the household economical status.

\section{Kenya's Commitment to Basic Education For All (BEFA)}

Declaration of human rights signed in Paris in 1948 included the right of each individual to education. This interest in education inspired the newly independent countries to hold UNESCO sponsored conferences on education with intention to spread education to all. The most notable of these conferences took place in Addis Ababa in 1961 where African countries agreed to aim at attaining Universal Primary Education by 1980 and at the same time planned to expand all other levels. Ayot and Briggs (1992-94) observe that the people of the new nations had often been promised education for all by their leaders before independence and saw education as an essential factor for personal advancement.

In Kenya the provision of Educational opportunity has been a standing objective of the government since independence. This is because education is considered by different stakeholders in the country as an important vehicle for self advancement, social, economic as well as political development. The KANU Manifesto (1963:140) described it as a social service and therefore the responsibility of the government. As a matter of fact, needless to say it is clear that 
when Educational opportunities are opened to girls and women, such benefits are even greater. From this perspective the sixth National Development Plan 1989-1993 states that Kenya has fundamental goal for education to prepare and equip the youth to be happy and useful members of the Kenyan society. To be happy they must learn and accept the national values and to be useful they must actively work towards the maintenance and development of the society.

In line with the eighth National Development Plan 1997 - 2001, one of the government guiding philosophy for education was the concern that every Kenyan had the inalienably right to basic education. Since independence, the expansion of education facilities has been the single most important challenges on the human resource development front. The government is now committed to providing basic education to all children for twelve years. It is also true that one of the rationale given for the introduction of the 8-4-4 system was to ensure that the student graduating at every level has some scientific and practical knowledge that can be utilized for either self-employment, salaried employment or for further training. However, it is evident now that the practical subjects that were introduced at the beginning have since been removed from the syllabus.

Sessional paper No. 1 (2005) therefore proposed that secondary education be integrated as part of basic education. Hence, basic education comprised primary education of eight (8) years for those in $6-13$ years age bracket and secondary education of four (4) years for $14-17$ years old. Ideally this means that every Kenyan child should be in a school for at least twelve years and he / she must have access to secondary education. It is important to do this because at 14 years the primary school leaving age children are still too young to take up any form of employment and hence may be exposed to exploitative labour (MPET 1998). However, this will remain an uphill task unless the issue of transition from primary to secondary school is addressed.

The master plan for education and training - MPET (1998) that sets a road map to reforms in education in Kenya has to steer the country towards the development. The role of education can be summarized as assisting the establishment of the human resource base necessary for the generation of wealth and more importantly its application of the creation of higher standards of living and improved quality of life.

Above all, Kenya is a signatory of UN Convention on the Rights of the Child (1991) and the African Charter on the Rights and Welfare of the Child. The government has also put in place a policy framework and appropriate legislation that ensures provision of education to all children regardless of their circumstances. Key among them is the Children's Act of 2001, which proclaims that education is a basic right for all children. Realizing that free and compulsory education is necessary for achieving universal education, the government of Kenya introduced free primary education policy in 2003 which is in line with the commitment of achieving Education for All (EFA) and more so basic education for all by the year 2015.

\section{Kenyan Education Planning and Policy Evolution}

The education in Kenya was introduced by the British colonialists. Since independence the government has addressed challenges facing the education sector through commissions, committees and taskforces. The MOEST (2004) Policy Framework on Education, Training and Research in Kenya in the $21^{\text {st }}$ Century.

These include:

- Ominde Education Commission of (1964) which proposed an education system that would foster national unity and creation of sufficient human capital for national development.

- The Gachathi Report (1976) which focused on redefining Kenya's educational policies and objectives giving consideration to national unity and economic, social and cultural aspirations of people of Kenya.

- Mackay Report (1981) Presidential Working Party on the second university in Kenya. This led to the removal of Advance (A level) of secondary education and the expansion of other post secondary institutions.

- The Kamunge Report (1988) Presidential Working Party on Education and Manpower Training for the next decade and beyond. It focused on improving financing, quality and relevance.

- The Koech Report (2000). The Commission of Inquiry into the education system of Kenya. It recommended Totally Integrated Quality Education and Training (TIQET)

The initial commissions and reports aimed at policies fostering national unity and creation of sufficient human capital. They were adopted from the colonial government. The reports in 1980 were more focused on redefining Education to foster national unity, social, economic, and cultural aspirations of Kenyans. Issues concerning education financing, quality, and relevance were introduced in the 1990s. In 2000 the commissions of inquiry into education system (The Koech Report, 2000) recommended the Totally Integrated Quality Education and Training (TIQET) It outlined ways and means of enabling Education to facilitate lifelong learning national unity and mutual social responsibility, accelerated 
industrial and technical development while responding to changing circumstances (MOEST 2005) The findings from these initiatives have not been used as expected and recommendations were either ignored completely or implemented only in parts. The 8-4-4 system of education was introduced through the Mackay Report of 1981. However through the subsequent commissions and taskforces the system has been in many occasions adjusted to fit the desired needs for the country and the internationals education objectives.

\section{Current Education Planning and Policies}

According to MOEST (2005) Sessional Paper No. 1, the recent policy initiatives have focused on the attainment of EFA and in particular Universal Primary Education (UPE). The key concerns are access, retention, quality and relevance and internal and external efficiencies within education system. The government is committed to the provision of quality education and training as a human right for all Kenyans in accordance with the Kenyan law and the International Conventions such as EFA Goal, Millennium Development Goals (MDGs) of the United Nations and the aims to achieve the Kenyan Development goal of vision 2030. Education sector report (January 2008) confirms that the education sector in Kenya has continued to undertake reforms introduced in the last 3 years, in order to address the overall goals of the National Economic Recovery Strategy for employment and wealth creation as well as National and International development commitments, including the Millennium Development Goals (MDGs) and Education for All (EFA). However there is need to identify the key objectives for the FSE policy as outlined in the Nationals Action Plan on Education For All 2003-2015 (MOEST, 2003).

i. $\quad$ Transition -An effort to deal with the race for demand for secondary Education following success of FPE.

ii. Man power reason for economic and industrial development in order to achieve vision 2030.

iii. To achieve international agendas, that is the EFA and the MDGS.

iv. Eradication of poverty through social mobility created by education access, retention, quality and transition through government education funding the basic education which is the first 14 years (pre-primary, primary, secondary education).

In Education sector report (January 2008) the Ministry realized that in order to continue realizing increased access and equity as well as improved quality and relevance of education research and training is important. The sector will continue implementing the Kenyan Education Sector Support Programmes (KESSP). The education sector report (January 2008) reports that despite the progress made there are still challenges in terms of enhancing access, equity, quality, relevance and governance. To address some of the identified challenges, the (2008) Education Sector Report therefore come up with a policy to promote access and transition to the secondary education. That is enhancement of access and equity that will entail provision of infrastructure to deepen the gains of FPE and address the concomitant infrastructure needs with the envisaged higher enrollment once the new policy on Free Secondary Education (FSE) funding policy is adopted.

According to Education Sector Report (2008) transition rates from primary to secondary schools has been highlighted as a big challenge to the education sector. However, according to this report, one of the strategic objectives of education sector is to increase transition rates from primary to secondary education to 70 percent in 2008, 80 percent in 2012 and 90 percent in 2015. According to Resource requirements for the MTEF period 2008/09 - 2010-11 by MOEST (2008), the overall policy priorities that resource requirements target relate to improving access, relevance, quality and equity in the provision of education and training at all levels taking into account disparities at district levels. It also improves efficiency in resource utilization and integration of development systems for national and global competitiveness.

The report also highlighted the priority areas of expenditure in education sub-sector in primary and secondary education while ensuring high sustained enrollment rates, quality completion and transition and equity. The report pinpoints out that the emphasis will be geared towards support of both education including provision of instructional materials, schools feeding programmes, special support for primary and secondary schools in Arid and Semi-Arid Area (ASALS), Support for alternative education delivery methods, improving school environments by providing physical facilities and equipment and hiring teachers to address the current shortage as well as replace those who leave through natural attrition. In this sense, it is imperative that the quality of education being given through the FSE programme undergoes the quality test to identify whether there are gains made in education under the new programme through provision of other support to various different groups of schools. 


\section{Secondary Education Sub-Sector in Kenya}

Formal secondary education in Kenya is the second level in the education system which caters for $14-18$ years within the school system (MOEST, 2005). EMIS Unit indicates that there has been a massive increase in enrollment in primary schools following the introduction of FPE which is already putting pressure on the demand for and access to secondary schools (Ministry of Education, 2008). The immediate challenge is how to expand access at relatively low cost in the Secondary school, while improving the quality of education at the same time. The momentum for rapid and urgent expansion of secondary Education will become more crucial as FPE becomes more universal (MOEST, 2008).

\section{Issues and Constraints}

Kenya Education Sector Support Programme 2005 - 2010 paper (May 2005, MOEST) indicates that there has been a decline in secondary school enrollment. The paper shows that the decline has been caused by the following factors:

- High cost of learning and teaching materials, school uniform transport and development levies.

- Extra expenses for private tuition.

- Unfriendly school environment especially for girl child like in situations where there is no privacy in toilets.

- poverty at household levels

- Negative effects of HIVIAIDS pandemic

- Rising repetition rates

- Low expansion of public secondary education of public secondary education in urban areas, especially Nairobi.

Besides the above factors, KESSP (2005) indicate that the cost of secondary education in boarding schools is higher than the day schools by more than 50 percent.

Secondary education is also characterized by poor performance in national examinations especially in core subjects such as mathematics and sciences. The student text book ratios are also high especially in the rural areas and urban slums. The teacher factor is also important in explaining the poor performance; in that although the majority of teachers are graduates and approved teachers most of them are arts subjects oriented. This leads to shortage of teachers especially in Mathematics, Sciences, English and Kiswahili. In addition, secondary schools teacher training combines teaching methodology and subject masterly which undermines teachers' effectiveness in content delivery. Under this system both academic and methodology suffer from an overburdened programme.

Sessional Paper No. 1 (2005) identified ways to address the challenges facing the implementation of the policies that would promote the targeted transition rates from primary to secondary of 70 percent with a doubling by 2008 and tripling by 2015. Such an ambitious target could only be met by a partnership between the government, private sector, communities, non-governmental organizations and parents. Efficiency improvements, policy reforms and operational plans are therefore needed to accompany the expansion of secondary education.

According to the observation made the foundation of the need to expand access, equity, quality and transition at relatively low cost secondary education has been assessed. Therefore the need to integrate secondary education as part of basic education in Kenya has been done through provision of affordable secondary education through FSE funding policy.

\section{Overview of Transition from Primary to Secondary Schools in General}

Transition rates to secondary schooling are almost always above 95 percent in industrialized economies. This is not the case with most countries in the Sub-Saharan Africa. UNESCO report (2000) indicates that the problems of the poor transition from primary to secondary school level have remained a matter of concern in most countries in Sub-saran Africa. In fact the transition rates to secondary schooling in this part are lower than 50 percent .It is particularly worrying because educationist considers secondary education critical to the nurturing of the countries human resource since it is viewed as a gateway to social economic advancement.

Since few children complete primary school, those who do must be able to continue their schooling to secondary in order for student and society to reap the full benefits of their investments in educated population. Kirungi (2006) observes that failure to absorb the growing number of primary schools leavers will undermine universal primary Education and broader goals like elimination of poverty .Unfortunately, this is exactly what is happening. Currently, 83.8 percent attends primary schools but the rate drops to 59.3 percent of secondary school (Huebler, 2007). 
The transitional rate to secondary school or the percentage of children who continue to secondary schools is 67.1 percent for East and Southern Africa and only 52.4 percent for West Africa. This trend contrasts sharply with the 98 percent worldwide (Huebler, 2007). In fact as, UNESCO (2006) fact sheet puts it in one out of every four African countries, just half of the children enroll at the end of the primary school level. In another 25 percent of African countries ,only one of three continue into the secondary school level and in two countries -Tanzania and Burundi, less than 20 percent of the children do so.

The reasons for this low transition are many. As UNESCO (2006) explains some families cannot afford to keep their children in secondary school. In some countries there is simply no enough places in secondary schools and so authorities screen children though public examining or by using other methods.

Children have a right to education that guarantees them full participation in society and the economy. It is clear that in addition to the large investments being made in primary education, the world should make secondary education an equal priority. Renewed push to ensure that children have access worldwide to secondary school as well as primary. Education is necessary now, if the investments made to date are to pay off for children, their communities, their countries, and the world.

\section{Transition to Secondary School in sub-Saharan Africa}

A study conducted by Aketch and Rolleston (2007) funded by APHRC - Africa Population and Health Research Centre, shows that the majority of children in Sub-Saharan Africa do not make it to secondary school. Analysis of Gross Enrollment Rate (GER) shows that two thirds of all countries with secondary GER of $40 \%$ and below are in Africa. Current statistics from the APHRC demonstrate that in Sub-Saharan Africa, only a small minority participates in and finishes secondary schooling. This brief indentifies major reasons that prevent children in Sub-Saharan Africa from effectively transitioning to secondary school, Kenya being one of them (Aketch and Rolleston, 2007).

\section{Factors Influencing Transition to Secondary School in Sub-Saharan Africa}

According to APHRC, there are four critical factors that have been identified as being major hindrances of transition rates, Kenya being one of the Sub-Saharan countries hence the need of FSE policy. A research by the World Bank (2005) indicated that secondary Education in most African countries tends to be neglected, receiving an average of 15200 percent of state resources. This therefore means that the cost is a key barrier to transitioning to secondary school for the poor who form the majority in the Sub-Saharan Africa. This is the same scenario in Kenya, since most Kenyans population belong to the poor household. Therefore the government of Kenya has attempted to integrate secondary education as part of the basic education. This is a move to improve transition from primary to secondary school of the children from the poor background. Hence the study sought to investigate the effect of the FSE policy on the transition rates from primary to secondary sub-sector. The major hindrances include,

\subsection{Financial Factor}

A study conducted by Aketch and Rolleston (2007) indentified financing secondary school education as a great challenge to both government and households. Secondary education in most African countries tends to be the most neglected receiving an average of $15-20 \%$ of state resources. Household burden in financing secondary education is still high. In Kenya, whereas households meet only $20 \%$ of primary and $8 \%$ of university education costs, they shoulder $60 \%$ of secondary education costs. Thus, the cost is a key barrier to transitioning to secondary school for the poor who form the majority in Sub-Saharan Africa. The Kenyan government argues that affordable secondary education is one of the solution to ensuring on equal chance to all student to transit from primary to secondary in spite of what kind of household they are from, whether poor or rich.

\subsection{Family Networks and Household Composition Factor}

Policies of FPE and secondary in East Africa showed that, poor households in Sub-Saharan Africa, family networks are important since the burden of educating children is shared by extended family members where the family networks are strong. Household composition is important because studies have shown that the chances that a child would access secondary schooling decreases with the number of children in secondary age cohort in the household. However, with the 
Kenyan government funding each child would have a chance to access secondary education regardless of the household composition (Aketch and Rollerstone, 2007). According to MOEST (2005) a policy framework for education, training and research states that the poor and disadvantaged students would be assisted through secondary school bursaries, hence the introduction of FSE policy shall go a long way in alleviating the problems related with poverty at household levels which hinders the transition rates from primary to secondary sub-sector in Kenya.

\subsection{Quality and Relevance Factor}

Research conducted and funded by the world Bank (2005), points out that due to Perceptions of curricular inadequacies and low quality of education across many nations have given rise to apathy, school disaffection and anti social behaviors' on the part of the students, often leading to low transition from primary to secondary sub-sector. Such students tend to focus on other forms of economic investments that are likely to give them and their families' immediate economic returns. Through the FSE funding policy, education quality and relevance inadequacies have been addressed. Therefore, the students would concentrate on education hoping to gain more economically after they have achieved higher education.

\subsection{Inequitable Distribution of Secondary Schools Factor}

There is existence of uneven distribution of education opportunities between poor and non-poor regions both in urban and rural areas. The poor tend to have more limited access to educational opportunities than the non-poor. For the case of Kenya, a research conducted by Knight and Sabot (1990), show a justification of expanding secondary school education. In their findings, they say that secondary education has a role of equalizing incomes and its potential by reducing the transmission of integration inequality. However in their research, it was noted that the expansion of Kenyan secondary system has given rise to selection by family background in Kenyan labour market. Thus the family background has an effect on the type of school attended and results achieved. Less privileged students were more likely to attend the poorer quality harambee schools which also received less government subsidy thereby worsening inequalities, hence, the introduction of FSE to bridge the gap between various households.

Research conducted by Knight and Sabot (1990) showed that cost and household economic ability had effect on the secondary school attended depending with the family background. This study clearly indicates that introduction of FSE policy would remove the inequalities in accessing government secondary schools for all the students joining secondary schools, from whichever background. Hence the study seeks to identify effect of FSE policy on transition rates from primary to secondary school in Kenya.

In an effort to deal with the race for the demand for secondary education after implementation of FPE government in the (2005) Sessional Paper No. 1 on educational Planning and Policy, outlined the government policy working towards integrating secondary education as part of basic education in the long term would be done through promoting the development of day schools as a means of expanding access or reducing costs to parents. Also, provision of targeted instructional materials to needy public secondary schools

However, the four critical factors mentioned above influencing transition to secondary schools may not apply uniformly. This is because Sub-Saharan Africa is very diverse. Hence according to APHRC there exist major research gaps in relating to specific factors impending transition to secondary school within specific and /or identifying factors impending transition to secondary school within a specific context. Nonetheless, the lack of schools within a reasonable distance is serious problem in rural areas, often marginal and remote parts of the countries. This limitation is shared with urban slums that are often neglected in the provision of basic infrastructure. The rural urban poor also share other common characteristics in constituting a majority of the poor that cannot afford and programme to significantly improve transition to secondary school in the region; they must target these segments of population. Hence, the implementation of FSE policy in Kenya ensures all Kenyan children are able to access basic education in which secondary education has been integrated. Hence, the study seeks to identify the effects of the FSE implementation in relation to transition rates from primary to secondary education sub-sector.

\section{Transition from Primary to Secondary Schools in Kenya}

Before January 2003, the number of Kenyan children to be out of school was over three millions. Children right to education had been curtailed by the cost sharing policy in Education which made schooling unaffordable to many families (ANPPCAN, 2000). This saw many children pushed out of school and subsequently found their way into child labour 
situations. It was therefore very welcome when the National Rainbow Coalition (NARC) Government that took power at the beginning of 2003 implemented FPE policy. This has seen estimated 1.3 million children getting back to school. Despite Kenya having one of the highest secondary school enrollment compared with majority of the other countries in the sub-Saharan Africa. However, the percentage of transition has been around 46.1percent and 46.4 percents 19992003 but in 2004 the rates increased to 50.5 percent (MOEST, 2004).

In fact after release of 2005 Kenya Certificate of Primary Education. The minister of education acknowledged that more than 290,000 candidates who sat for examination would miss secondary education places. In order to address this challenge the government implemented the policy of integrating secondary education as part of basic education. Thereafter, in order to promote means of increased access the government has promoted the development of day schools. Therefore the study was conducted to find out whether the introduction of FSE policy has changed the transition rates from primary to secondary sub-sector of education.

Kenyan is a signatory to several international conventions that aim at promoting Education. These include the United Nation conventions on the rights of the children and African charter on the rights of welfare of the child, which provide for education as a basic right for all the children. The realization of making Education free and compulsory is key in the struggle to achieving universal education prompted the Kenyan government to begin implementing the FPE policy in January 2003. However, in spite of the commendable efforts that Kenya has made towards this, achieving Education EFA still remains an uphill task, unless the issue of transition in Education especially from primary to secondary school is adequately addressed. Transition from primary to secondary level still remains a challenge and is sure to undermine the gains made in Education sector. Many children ,particularly in the age of 14- 18 still remain at risk of lack of access to education and child labour including domestic workers, commercial sexual exploitations, mining, fishing, and quarrying just to mention a few(ANPPCAN, 2004).

The issue of transition in Education is of grave concern today than before because of the number of children who are unable to proceed to post primary education .Out of 587,961 candidates who sat for their KCPE at the end of the year 2003 only 270,205 got chances to proceed to secondary schools (Onyango, 2004). This means that the remaining 317,756 , (over 54 percent) of the children who completed primary school are unable to get opportunity to further their education. This therefore has remained the trend for the last two decades. This means that there is desired needs to addressed the issue of transition with effective intervention that would cater for the over 300,000 children who are unable to proceed with further education (ANPPCAN, 2004).

MOEST in collaboration with other key players has put several measures to enhance transition from primary to secondary schools. These include elimination of school levies and other barriers to increase access to primary school education, providing bursary for the needy secondary school students and establish a policy for expansion of existing secondary schools.

MOEST in attempt to achieve higher transition rates considered some, recommendations made by, Sifuna (2004) come up with recommendations that would make primary school leavers to access secondary education one being, expansion of basic education from 8-12 years, in line with the proposal made in Koech report of 1999 (Republic of Kenya, 1999). This would give an opportunity to every Kenyan child to attain a minimum secondary education. The Koech commission recommended massive expansion of secondary education country wide. In this regard it proposed a deliberate effort to control fee payment in secondary school education and set fee ceiling recommended by the MOEST be adhered to. However this strategy has always failed to address the needs of the marginalized groups. Therefore the government through MOEST embarked on provision of Affordable Secondary Education in attempt to provide equal chances to all primary school graduates to transits to secondary schools regardless of their social and economic background. Subsequently the study was carried out in order to investigate the effects of FSE on transition rates from primary to secondary schools in Gatundu District of the central province.

\section{Conclusion}

The from its discussion, this paper has identified the challenges and success of education especially in the Sub-Saharan countries. The reviewed literature points out that most countries consider education as a vehicle to transform members of the society to productive members. This indicates that all the countries especially in transitional economies has embarked on heavy investments on education which is believed to be the only way out to achieving full economic development as indicated.

Kenyan government has taken the same path in its attempt of achieving economic development. The paper indicates that the government has spent reasonable resources in attempt to clearly channel the path to be taken in 
Education programmes in future. The integration of secondary education as part of basic education means that the main objectives are to increase the access and participation, reduce the high cost of secondary school education to household, improve quality and more so enhance the transition rates from primary to secondary sub-sector of education

Therefore the may embark on ascertaining the enrollments increase or decrease after the implementation of FSE policy, identify the role of the principals and District Education officers and QASOs in the implementation of the FSE policy. The study may also ascertain the patterns and trends of transition rates from primary to secondary schools before and after the implementation of FSE policy. Besides the literature review indicates that the Kenyan overall objective of VISION 2030 is to transform the country into a globally competitive and prosperous nation with quality of life.Secondary education has been viewed as a major contributor to this objective, hence introduction of affordable secondary education.

\section{References}

Abagi, O. \& Odipo, G. (1997). Efficiency of Primary Education in Kenya. Situational analysis implications (IPAR) Discussion Paper No 00497195. Nairobi, Regal Press.

Aketch, M.O \& Rolleston C. M. (2007). Policies of Free Primary and Secondary Education in East Africa (CREATE).

Ampiah G.J and Adu-Yeboah C. (2009). "Mapping the incidence of school drop out: acase study of communities in Northern Ghana' Comparative Education, Vol.45: Issue 2,pp219-232.

ANPPCAN, (2004). Report of civil society symposium on enhancing Transition in Education for Primary School Leavers Feb 2004, Nairobi.

Basic Education For All. Three Years After Jomtein (1993) UNICEF. UNESCO.

Cameroon J. (1970). The Development Of Education In East Africa. Teachers college: New York.

Central Bureau of Statistics, (2004). Economics Survey 2004. Nairobi: Government Printer.

Cresswell, J.W; (2003). Research Design: Qualitative and Mixed Methods Approaches thousand Oaks: Sage Publications.

Education For All in Kenya. A National Handbook on EFA 2000 and beyond MOEST (2001)

Elleni T. (1995). Sankfora, African Thought and Education. Peter Long: New York.

Eshiwani, G. S., (1984)Factors influencing Performance among Primary and Secondary School in Western Province Policy Study, (Kenyatta University College). Bureau of Educational Research.

Gay. L. R. (1992), Educational Research, Competences for Analysis and Application. Ohio: Charles E. Merill Publishing, Co.

Huebler, F. (2007). Education statistics .Quoting UNESCO Global Education Digest 17 July 2005.

Hunt, F. (2008).' Dropping out from school': A cross- country review of literature. Create pathway to access No 16 . Consortium for Research on Educational Access, Transitions and Equity: University of Sussex.

Kenya Education Sector Support Programme 2005 - 2010. Delivering Quality Equitable and Training to all Kenyans MOEST (2005)

Kenya National Bureau of Statistics, (2008). Economic Survey 2008 Nairobi. Kenya National Bureau of Statistics

Kiess, H. O. and Bloomquist, D. W. (1985), Psychological Research Methods: A Conceptual Approach. Boston. Allyn and Bacon.

Lewin K.M. (2008). 'Access, Age \& grade.' Create policy briefs No.2. Consortium for Research on Education Access, Transitions \& Equity: University of Sussex.

Lookheed, E. M, Vers Poor, A. M. \& Associates (1991). Improving Primary Education in Developing Countries: Oxford Press.

Ministry of Education (2005)Kenya Education Sector Support Programme 2005-2010 ww Education.co.ke

Ministry of Education, (2008). Education Realizing Vision 2030 goals through Effective and Efficient Public Spending

Ministry of Education, Science and Technology (2005a). Sessional Paper No. 1 of 2005 On A Policy Framework for Education, Training and Research. Nairobi: Government Printer.

Mugenda, A. \& Mugenda, O., (1999). Research Method Qualitative Approaches Nairobi Africa Center of Technology Studies.

Mutahi, K. (2004). Enhancing Transition in Education for Primary School Leavers Opening Speech, Nairobi ANPPCAN.

Orodho, J. A. (2009). Elements of Education and Social Science Research Methods. Maseno, Kenya, Kanezja Publishers.

Orodho, J.A. \& Njeru E. (2003). Access and Participating in Secondary School Education in Kenya. Emerging issues and Policy Implications.(Government of Kenya). Nairobi: Government Printers.

Otieno, W. \& K'Oliech D. (2007). Factors Affecting Transition to Secondary Education in Africa. MOEST (2007)

RAESK (2003). Reform Agenda for Education Sector In Kenya and Legislative Framework. Nairobi: Elimu Yetu Publisher.

Ramya, S. (2008). Millennium Development goals (status report for 2007)Government of Kenya. Nairobi: Government Printers.

Republic of Kenya, (1988) Sessional Paper No 6 . Nairobi, Government Printers.

Republic of Kenya, (1998). Master Plan on Education (1998) Master PLAN on Education and Training 1997-2010 Nairobi. Jomo Kenyatta Foundation.

Republic of Kenya, (1999) Commission of Inquiry Report . Nairobi, Government Printers.

Shiundu, J. S. \& Omulando, S. J. (1992). Curriculum Theory and Practice in Kenya. Nairobi, Oxford Press University.

Sifuna, D. (2004). Policy and Programme Options for Enhancing Access To Secondary Education for Primary School Leavers. Nairobi, ANPPCAN.

Singleton, R. A., (1993). Approaches to social Research. New York University Press.

Stabler E. (1969). Education since Uhuru; The Schools of Kenya. Wesleyan University Press: Middle Town. 
UNESCO, (2001). Financing Secondary School Education in Developing countries Strategies for Institutes for Statistics Fact Sheet January (2006)

World Bank, (1988). Education in Sub-Saharan Africa Washington D.C Bank.

World Bank, (2000). World Development Indicators .2000 Washington D.C. World Bank.

Wiersma, W (1995). Research Methods in Education: An Introduction. (2nd Ed) Boston: Allyn Bacon Inc.

Psacharopoulos G and Woodhall (1985): Education for Development: An Analysis of investment choices. Oxford University Press.

Republic of Kenya, (2005). Sessional Paper No. 1 of 2005 on a Policy Framework for Education, Training and Research. Nairobi: Government Printer. 